\title{
GROWTH ASPIRATIONS AND SOCIAL CAPITAL: YOUNG FIRMS IN A POST-CONFLICT ENVIRONMENT
}

\author{
Adnan Efendic, University of Sarajevo, Bosnia and Herzegovina \\ Tomasz Mickiewicz, Aston University, UK \\ Anna Rebmann, University College London, UK
}

CONTACT: Tomasz Mickiewicz; t.mickiewicz@aston.ac.uk; (T) (+44) 121204 3007; Aston Business School, Aston University, Aston Triangle, Birmingham, B4 7ET, UK

Forthcoming in International Small Business Journal

\section{ACKNOWLEDGEMENTS}

This research was supported by a grant from the CERGE-EI Foundation under a program of the Global Development Network. All opinions expressed are those of the authors and have not been endorsed by CERGEEI or the GDN. In its initial stage the research was supported also by Microcredit foundation "Prizma" Sarajevo.

We are indebted to the editor of this journal; the journal's reviewers; Elodie Douarin, Ute Stephan and Aziz Sunje. We also thank to the reviewers and participants of the Academy of Management conference in Orlando; of BCERC in Lyon; of ISBE in Cardiff; of ICES in Sarajevo; seminars at Aston University and Staffordshire University in UK, for their useful comments and criticism.

\begin{abstract}
We explore growth aspirations of young firms' owners and managers in a post-conflict economy by focusing on social capital. We treat social capital as a multi-dimensional, multi-level phenomenon; studying the effects: of owners' and managers' discussion networks' characteristics, trust in institutions, generalised trust in people, and local ethnic pluralism. We argue that in a post-conflict country, ethnic pluralism is indicative of local norms of tolerance towards experimentation and risk taking, which supports growth aspirations. We also distinguish between the aspirations of hired managers and owners-managers. Our empirical counterpart and hypotheses testing rely on survey of young businesses in Bosnia and Herzegovina.
\end{abstract}

\section{INTRODUCTION}

In this paper we focus on the effects of various determinants of social capital on growth aspirations of owners and managers of young businesses in a post-conflict country - Bosnia and Herzegovina (BiH). Post conflict environments are fragile yet may also offer opportunities for economic turnaround, therefore call for particular attention (Collier, 2008). Our interest is in the micro foundations of the process of economic recovery. In particular, we ask what factors affect growth aspirations of young firms. Consistent with Penrose (2009 [1959]) we posit that growth strategies of firms need to be primarily attributed to managerial capital; moreover, it is in the early stage of business activity, in young firms, that the growth dynamism is particularly constrained by management. Penrose's (2009 [1959]) stress on management is consistent with the view that sees entrepreneurship being "about people in their roles as identifiers of opportunities and the exploiters of opportunities" (Acs, 2006, p. 195). Enterprise is as much about growth as about emergence of new firms (Penrose, 2009 [1959]), and growth is the critical stage of their development (Wright and Marlow, 2011). Yet unlike some of the open and stable economies, in a post-conflict environment growth aspirations can be easily damaged. In particular, where much of social capital was destroyed during the war, it becomes the key limiting factor affecting aspirations. It is in this context, we consider the micro-, meso- and macro-level aspects of social capital that affect managerial growth aspirations of young firms. We believe that our lessons apply to other postconflict environments; moreover we also agree with Light and Dana (2013) who stress that the general boundaries of social capital might become more evident in settings other than conventional.

As will be discussed, we focus on the social links seen from the manager's perspective. However, we treat social capital as a multi-dimensional and multi-level phenomenon, in particular considering social links at micro and meso level, with macro level treated as the context. In particular, we study the effect of owners' and managers' discussion networks on growth aspirations, and also of facets of meso-level social relations that support entrepreneurship, such as trust in institutions and people. We argue that in a country with weak 
institutions, there is a wider meso-level variation compared with countries with strong institutions, where the institutional environment is more homogenous. In addition, we posit that in a post-conflict, multi-ethnic country, such as $\mathrm{BiH}$, the presence of ethnic pluralism is an indicator of local social norms of tolerance that facilitate experimentation, competition, enterprise and growth aspirations.

With the exception of Kwon and Arenius (2010) and Estrin, Korosteleva and Mickiewicz (2013), the social determinants of growth aspirations are not yet attracting the attention they deserve (e.g. Autio and Acs, 2010; Levie and Autio, 2011). This reflects a broader gap in the entrepreneurship literature: while there is "increased appreciation for the importance of social relationships in entrepreneurship" (Gedajlovic, Honig, More et al., 2013: 455), the influence of these factors on enterprise development remains under investigated (Thornton et al., 2011). Yet negative social and cultural influences may eradicate high growth aspirations entrepreneurship (Van Stel and Storey, 2004) and thus affect entrepreneurial performance. This becomes clearer, once we move away from a standard context like that of local settings of a mainstream developed economy, and consider alternative social environments (Light and Dana, 2013).

Thus, by widening our perspective and considering a post-conflict environment deficient in social capital, we may also enhance our general understanding of the social phenomena supporting entrepreneurial aspirations. Seen within this wider context, the focus on social capital follows Granovetter's (1985) call to avoid both "oversocialized" and "undersocialized" theories: the former put stress entirely on macro-level social structures (e.g. Marxist-type social class analysis), while the latter model considers individuals as atomized, abstracting from any social features (see also: Estrin, Korosteleva and Mickiewicz, 2013). Accordingly, we focus on the links between entrepreneurship and social dimensions in a post-conflict context. It is in such case that the social capital may be both most fragile and most needed. We examine the case of a specific country $(\mathrm{BiH})$ that is emerging from a recent conflict (1992-1995), yet our analysis offers lessons that may be applicable to other similar environments.

The paper is organized as follows. In the introductory section, we briefly discuss the context: the ethnically complex post-conflict environment and current state of entrepreneurship in BiH. Next, we introduce the research framework and hypotheses. Subsequently, we discuss the data and model specification respectively, before reporting the key empirical findings. Finally, we offer conclusions.

\section{CONTEXT: ENTREPRENEURSHIP IN BOSNIA AND HERZEGOVINA}

In the late ' 80 s and early ' 90 s of the previous century, the ex-Yugoslavia (including $\mathrm{BiH}$ as an ex-Yugoslav republic) was overwhelmed with unresolved internal political and economic issues. The (inconsistent) transition reforms started during this period and were supposed to strengthen the internal cohesion and bring in economic improvement, but in practice contributed to the disintegration of ex-Yugoslavia (Hadziahmetovic, 2011). A four-year war began in $\mathrm{BiH}$ with recognition of its independence in 1992 and brought massive destruction. Signing the Dayton Peace Accord (DPA) ended the war in 1995, yet at that moment, BiH had lost around $1 / 4$ of population and $3 / 4$ of its economic potential compared to 1991. Estimated GDP per capita has fallen from 1,900\$ to around 500\$ by 1995 (World Bank, 1997).

BiH today is a middle-income country where, like in other Central and East European (CEE) nations that have been transiting from a planned to a market economy, the entrepreneurial growth aspirations are limited. Autio (2011: 259) defines high aspirations early stage entrepreneurs as owners-mangers of businesses that are less than 42 months old, who "expect to employ twenty or more individuals within five years' time". The prevalence rate of high aspirations entrepreneurs in $\mathrm{BiH}$ amongst adult population is at low $0.5 \%$, similar to neighbouring Croatia and Serbia, affected by the same conflict in 1990s. This contrasts with several Latin American and South East Asian economies, where entrepreneurial dynamism is significantly higher, including between 2.0\%-2.5\% in China, South Korea, Peru and about 3.5\% in Columbia.

Data on high-aspirations start-ups is consistent with figures on numbers of micro, small and medium enterprises that are also low for transition economies (Estrin and Mickiewicz, 2011a); likewise levels of nascent entrepreneurship and new business ownership are below average. In 2010 from the transition countries surveyed, an estimated $7.6 \%{ }^{1}$ of their population aged $18-64$ was involved in starting a new business or running a business which was less than a year old (this figure is $7.7 \%$ for $\mathrm{BiH}$ ), compared to $11.7 \%$ for all middle income economies surveyed in 2010 (Kelley, Bosma and Amorós, 2010).

\footnotetext{
${ }^{1}$ Sampled transition economies in 2010 for Global Entrepreneurship Monitor are: BiH, Croatia, Hungary, Latvia, Macedonia, Montenegro, Romania, Russia. Slovenia was also sampled but is excluded from this group as it is categorised as an innovation driven or higher income economy.
} 
$\mathrm{BiH}$ as a part of ex-Yugoslavia (1945-1992) was a multi-ethnic republic with the highest level of ethnic tolerance (Hodson et al., 1994; Dyrstad, 2012). Unfortunately, the Bosnian war caused a structural break of the ethnic composition within the country, and $\mathrm{BiH}$ went through a radical change from ethnically tolerant to quite intolerant in just a few years (Dyrstad, 2012). Ethnic divisions created during the war period have largely been institutionalised by the constitution (Bieber, 2006). The multi-ethnic environment and pluralism was eroded, and preserved only in few parts of the country (Armakolas, 2011). The economic consequences of the artificially created new ethnic composition remain unexplored.

An investigation of the role of trust, networks and ethnic pluralism in relation to business development is particularly interesting in the context of $\mathrm{BiH}$, because of its ethnic and institutional structure. Three major ethnic groups make up the population of $\mathrm{BiH}$ : Bosniaks, Serbs and Croats (these ethnicities largely correspond to Muslim, Orthodox and Catholic religious traditions respectively). The war in the 1990s caused large population movements outside and within $\mathrm{BiH}$, leaving the population concentrated in more ethnically homogenous territories. Yet, ethnic minorities remain within areas dominated by Bosniak, Serb or Croat majority populations. Moreover, some areas avoided ethnic cleansing, preserving pluralism (Armakolas, 2011). Cultural differences are smaller than in other divided societies as the three groups speak virtually the same language, share similar traditions, and ways of thinking, which typically facilitate post-conflict reintegration (Collier, 2008). However, DPA which ended the war brought in a complex constitution that has institutionalised ethnic divisions (Bieber, 2006). Each of the three main ethnic groups has substantial autonomy and control over their own ethno-territorial units which predominate over the state level institutions (Bieber, 2010). Consequently, and rather uniquely, for each ethnic group there is some part of $\mathrm{BiH}$ where it remains an ethnic minority and some part of the country where it is the ethnic majority. Although there are no official indicators (the last census was in 2013, but with no data available yet at time of writing; the previous one was before the war, in 1991), there is casual evidence that ethnic pluralism is more present in regions which were less affected by the war activities, and therefore preserved more social linkages dating to the pre-war period (Armakolas, 2011). All this makes $\mathrm{BiH}$ a relevant context for studying the impact of social capital and ethnic pluralism on entrepreneurial aspirations.

\section{THEORETICAL FRAMEWORK}

\section{Entrepreneurial Growth Aspirations}

We follow Penrose (2009 [1959]: 30) in treating enterprise "as a psychological predisposition on the part of individual to take a chance in a hope of gain /.../". Moreover, "the decision on the part of a firm to investigate the prospective profitability of expansion is an enterprising decision, in the sense that whenever expansion is neither pressing nor particularly obvious, a firm has the choice of continuing in its existing course or of expanding and committing resources to the investigation of whether there are further opportunities of which it is not yet aware. This is a decision which depends on the 'enterprise' of the firm" (Ibid.: 30). Penrose emphasises that in such a decision, it is not the resource constraints, but managerial predisposition, which is the limiting factor. It is within such a perspective that we turn away our attention from a production function approach that would investigate resource constraints, towards considering managerial attitudes, predispositions, and strategies adopted to acquire new knowledge. In this theoretical perspective, the question about growth aspirations becomes important.

While Penrose (2009 [1959]) analysed growth decisions as dependent on managerial predispositions and their entrepreneurial character, one may argue that these decisions play a special role in the phase of entrepreneurial process when firms survived already the initial period of incubation, and they next decide if and how fast to expand (Messersmith and Wales, 2011). In this, we follow Estrin, Korosteleva and Mickiewicz (2013) who pay particular attention to growth aspirations of owners and managers of young companies, and more generally we build on the wider framework of those who see entrepreneurship as a process that includes several stages, not just a one-off transformation that creates a firm (e.g. Casson and Della Giusta, 2007; Wright and Marlow, 2011). The "spirit of enterprise" (Penrose, 2009 [1959]) is best captured by those companies that aspire to growth, in contrast with those that settle with their size defined by the initial period of establishment.

Accordingly, our study is located within a recent strand in the entrepreneurship literature focusing on the individual and contextual determinants of growth aspirations (Bowen and De Clerq, 2008; Autio and Acs, 2010; Levie and Autio, 2011; Estrin, Korosteleva and Mickiewicz, 2013). However, even if one is not interested in the entrepreneurial process, focusing only on achieved growth, there is a substantial body of research confirming the positive relationship between an entrepreneur's business aspirations and subsequent firm performance (Kolvereid and Bullvag, 1996; Baum et al., 1998; Baum et al., 2001; Wiklund and Shepherd, 2003; Delmar and Wiklund, 2008). Thus, growth aspirations are also important, because we know that they are significantly 
associated with the subsequent expansion of firms: managerial objectives shape actual outcomes. In turn, the dynamic new enterprises are drivers of economic growth (Wong et al., 2005; Henrekson and Johansson, 2010).

Based on the literature quoted above, we have some understanding of what shapes entrepreneurial growth aspirations. Yet, to our best knowledge, the issue has not been analysed with respect to a post conflict environment. It matters for two reasons. From a theoretical perspective, non-standard contexts help us to understand if some of the mechanisms we observe are general or not (Light and Dana, 2013). From a policy perspective, post-conflict environments need particular attention, because they offer both opportunities for economic turnaround yet face high risks of lapsing back into violence (Collier, 2008). The opportunities relate to breaking up some of the social and political structures that could inhibit economic dynamism in the past (Olson, 1982; Acemoglu and Robinson, 2012). The threats relate to a risk that initial weak economic dynamism may lead to social frustration, feed into extremism, and bring back violence. It is in this context that it is important to understand the micro foundations of growth.

\section{Social Capital}

The influence of socio-cultural determinants on entrepreneurship development is still understudied concept (Thornton et al., 2011). We frame our analysis utilizing the concept of social capital, referring to ties between people (Nooteboom, 2007). At the core of the concept is the idea that goodwill stemming from social relations is a resource for facilitating action (Adler and Kwon, 2002), and that social linkages formed in one social sphere may be appropriable and used in another sphere. "Appropriability legitimates a conceptual strategy of bringing under the one notion /.../ informal organisation, trust, culture, social support, social exchange, social resources, embeddedness, relational contracts, social networks and inter-firm networks" (Adler and Kwon, 2002: 18).

A key division in the social capital literature is based on the level of analysis (Halpern, 2005). For some authors social capital is a macro-level phenomenon in the sense of characteristics shared nationwide (Putnam, 2000), whereas others understand social capital as specific to the micro-level and belonging to individuals (Bourdieu, 1986; Sobel, 2002). This division also has influenced two major conceptualisations of social capital: one focusing on societal relations and the other on personal relations. The societal relations stream defines social capital as widely shared, cooperative social norms such as trust and reciprocity (Fukuyama, 1995; Putnam, 2000; Rothstein and Stolle, 2008). The personal relations stream focuses on the micro structural element of social relations such as the properties of social networks that the individuals can use to secure benefits (Bourdieu, 1986; Burt, 2000; Sobel, 2002).

More generally, business appropriable social capital depends not only on the network structure of an individual's social relations but also on the cognitive and normative structures that enable people to act collectively such as generalized and institutional trust. In this context, the meso-level becomes important. The latter relates to inter-group contacts (Pettigrew, 1998), where the social groups are wider than strictly personal networks yet narrower than macro level. Distinguishing between macro and meso level is also in the spirit of Granovetter's (1985) call to avoid "oversocialized" theories; Estrin, Korosteleva and Mickiewicz (2013) build on his insights, applying Granovetter's approach to determinants of entrepreneurial aspirations.

The distinction between the meso and macro level becomes critical in societies characterised by weak institutions. High quality institutions create homogenous expectations based on formal rules that generate shared understanding, and are consistently applied. In contrast, internal conflict undermines the rule of law and formal authority, replacing it with local informal structures of power, such as paramilitary or criminal groups (Armakolas, 2011). This is likely to leave a legacy after the conflict has ended.

Thus, in analysing the relationship between social capital and aspirations we follow suggestion by Wright and Stigliani (2012) and examine multiple dimensions of social capital attributing it to different societal levels (see Figure 1). Firstly, we examine how owners and managers relate to macro- and meso-level societal groupings. We argue that societal relations affect micro-level outcomes such as business aspirations and analyse the impact of ethnic pluralism, institutional trust and generalised trust on growth aspirations. Then we turn to personal relations, analysing the impact of discussion network composition on growth aspirations. We discuss all these dimensions next.

$<$ Figure $1>$

\section{Trust}

Trust is seen as a key dimension of social capital (Kwon and Arenius, 2010; Westlund and Adam, 2010). It indicates the presence of cooperative norms in society that enable the use of social relations to access resources 
(Paldam, 2000). Furthermore, it is seen as crucial component in the institutional structure of a market economy facilitating transactions (Arrow, 1974). However, not all trust is considered equally beneficial. A key distinction in the literature is made between 'particularised trust' (Rothstein, 2003) and 'extended' trust (Raiser, 1999). Particularised trust is trust emerging between two or more individuals such as family members and friends (Rothstein, 2003). It is based on knowledge of the individual or the fact that they belong to a particular group e.g. same ethnicity. Extended trust, in contrast, is more abstract, enabling transactions to take place with only limited information about the counterpart's specific attributes (Raiser, 1999). In this context, Fukuyama (2001) and Estrin, Mickiewicz and Stephan (2013) contrast "radius of trust" with "radius of distrust": social capital build within one group may have a negative effect on relations with other groups.

There are two main forms of extended trust: institutional trust (trust in institutions) and generalised trust (trust in unknown individuals). Institutional trust is trust in the functioning of the institutional framework including formal rules, organizations and enforcement mechanisms (World Bank, 2002). It is theorised to enable transactions outside the circle of known individuals, extending the radius of trust, as institutions can provide formal mechanisms which give security that a transaction will take place as promised (Zucker, 1986). If institutional systems are strong, institutional trust will be high and supportive to entrepreneurship development and business growth (Welter, 2012). Parallel to this, generalised trust is trust in unknown individuals (Rothstein and Stolle, 2008) and as such is a reflection of confidence in wide social norms, i.e. the expectation of accepted behaviour of individuals in society in general.

Raiser (1999) and Fukuyama (1995) argue that 'extended trust' is crucial to a modern market economy. Extended trust, unlike particularised trust, enables individuals to engage in transactions beyond closed circles of family or well-known business contacts, and such links are necessary for any complex division of labour. Extended trust offers enhanced cooperation and access to new opportunities (Rus and Iglič, 2005). In contrast, low trust environments are thought to hinder entrepreneurship, because businesses have to rely on particularised trust through personal networks, which increases transaction costs (Hohmann and Welter, 2002). We posit that this is particularly damaging to entrepreneurial growth aspirations. Growth is associated with increased complexity of transactions, and increased risks; it is here that the low trust and the low institutional quality environment becomes a binding constraint. Relying on particularised trust, individuals may successfully launch new businesses. However, they will keep them low scale when the perceived risks associated with expansion are too high (Aidis and Mickiewicz, 2006; Estrin, Korosteleva and Mickiewicz, 2013).

Moreover, transition economies are frequently characterised as low trust societies, due to their communist legacy (Fukuyama, 1995; Raiser, 1999; Estrin and Mickiewicz, 2011a). Trust in $\mathrm{BiH}$ has been further undermined by the recent war (UNDP, 2009). The conflict seriously damaged the rule of law, confidence in formal institutions, perceptions of equality under law, and of due judicial process. War brought "the radical redefinition of power relations, the blurring of distinctions between legal and illegal, state and non-state" (Armakolas, 2011: 231). An associated shift of perceptions is persistent and slow to reverse since "the manner through which the rule of law is or is not upheld in wartime profoundly influences the legitimacy of the state and the authority it commands among the population" (Ibid.: 231).

However, both Armakolas (2011) and Welter and Smallbone (2006) point out that trust also differs across regions and sectors. Norms of trust and perceptions of formal institutions can be diversified and localised. The way the individual entrepreneurs relate with the macro environment via institutional and generalised trust may also vary due to their individual characteristics, experiences and social status. De Soto (2001) argues that although nearly all ex-communist countries formally have universal property rights, in practice only some citizens, the elites, can get these formal rights enforced. Entrepreneurs coming from a poorer background and with fewer connections may in some countries feel less secure about their property rights or access to the legal system than those entrepreneurs who are better connected and wealthier (Glaeser, Scheinkman and Shleifer, 2003; Aidis, Estrin and Mickiewicz, 2008). The entrepreneurs feeling less secure are likely to scale down their growth aspirations due to threat of expropriation either by corrupt agents representing formal institutions, or by business partners coming from outside their radius of particularised trust; the growing size of the business venture would extend it beyond the radius of trust into social space of distrust. Accordingly, we hypothesise that the trust an individual expresses in relation to institutions (institutional trust) and to people (generalised trust) affects entrepreneurial growth aspirations positively. Combining the discussion above, we posit:

Hypothesis 1: The greater entrepreneurs' trust in institutions the higher their growth aspirations.

Hypothesis 2: The greater entrepreneurs' generalised trust the higher their growth aspirations. 


\section{Local Ethnic Pluralism}

According to the existing literature, ethnic diversity may have both positive and negative effects on economic outcomes, but is still being under-investigated in empirical research (Ram et al., 2011). On the one hand, where ethnic diversity is associated with fragmentation and conflict, it is likely to impact negatively on economic performance leading to poor economic choices and policies (Easterly and Levine, 2001). Putnam (2007) also argues that in the short run an increase in ethnic diversity is associated with less social capital and solidarity, although in the long run this effect might be different.

On the other hand, a diverse ethnic mix may bring various abilities, different experiences and ways of thinking, as well as a variety of cultures and traditions, which may lead businesses towards innovation, creativity and better economic performance (Alesina and La Ferrara, 2005; Florida, 2004, 2005; Smallbone, Kitching and Athayde, 2010; Lee, Florida and Acs, 2004). Such conditions are conducive both to a larger and more diversified pool 'of underexploited knowledge useful for commercialisation of new ideas' (Marino et al., 2012), and to low communication barriers that make access to this knowledge and its utilisation relatively easy, creating an environment for entrepreneurial dynamism. Consequently, "ethnic pluralism" (in contrast to "ethnic fragmentation") is a potential source of competitive advantage affecting entrepreneurial entry positively (Lee, Florida and Acs, 2004; Marino, Parrotta and Pozzoli, 2012; Audretsch, Dohse and Niebuhr, 2010; Smallbone et al., 2010).

We argue that at the meso level, ethnic pluralism in the social environment is advantageous to entrepreneurial growth aspirations. In $\mathrm{BiH}$, relations between the ethnic groups vary immensely not just between regions but also at the individual level. Thus, how individuals situate themselves in their ethnic environment is an important facet of social capital. It is likely that those entrepreneurs situating themselves as working in a more ethnically mixed area are also taking advantage of the opportunities that come with the more heterogeneous, but at the same time not fragmented, environment.

More than anywhere else, in a post conflict environment the local ethnic pluralism becomes an indicator of the relatively stronger local climate of tolerance. During the conflict, where present, this climate slowed down the eruption of ethnic hatred, which in turn prevented ethnic cleansing and preserved pluralism in social tissue (Armakolas, 2011). More generally, experience of ethnic pluralism via frequent face to face contacts may diminish prejudice and "lead to a less provincial view of outgroups in general" (Pettigrew, 1998: 72). The next step in this process is "generalisation from the immediate outgroup to other outgroups", that is: participation in inter-group links result in "greater acceptance of minorities of many types" (Pettigrew, 1998: 75). Therefore, experience of pluralism is associated with social norms that approve non-standard behaviour, including experimentation with new ways of doing things. Stephan and Uhlaner (2010) emphasize that the presence of such supportive social norms facilitates entrepreneurial behaviour, of which - as we discussed above - growth aspirations are a crucial aspect.

Growth aspirations are also enhanced by wider access to resources that comes with ethnic heterogeneity. Both Aldrich and Kim (2007) and Light and Dana (2013) emphasise that start-up teams are typically formed relying on close-ties social neighbourhood. It is only in the expansion phase that entrepreneurs face a need to recruit, reaching out for competences that may be available only in the wider and more mixed communities (Zain and Ng, 2006; Light and Dana, 2013). Thus, richer social links make scaling up entrepreneurial projects easier and therefore affects entrepreneurial aspirations positively.

Furthermore, working in a more ethnically mixed area implies that the entrepreneur has a more diverse "infrastructure" available for exchange of ideas, experiences and cooperation; hence, based on these opportunities to increase competence and knowledge, we expect ethnic pluralism to be positively related to managers' aspirations to grow their businesses. In contrast, individuals belonging to a homogenous ethnic majority or minority neighbourhood, in an ethnically fragmented environment, face a more narrow knowledge based, and this is likely to affect the entrepreneur's growth ambitions negatively.

Finally, it is also likely that more ethnically mixed areas create more competitive pressure: motivation to grow may not only result from opportunity recognition, but also from necessity: in some lines of business the

\footnotetext{
${ }^{2}$ In the context of our research questions, we prefer the concept of "ethnic pluralism" (an ethnically mixed locality, as opposed to an ethnically fragmented locality) over "diversity" as the former term captures better the aspects of co-existence and of inter-ethnic cooperation that we emphasise. We are grateful to the anonymous reviewer for the useful discussion of this point.
} 
companies may wish to expand in order to survive competitive pressure. Obviously, all these elements are not mutually exclusive. ${ }^{3}$

Hence, relating ethnic pluralism to supportive social norms, availability of resources (wider recruitment base in particular), knowledge, and competitive pressure to grow, we state the following:

Hypothesis 3: Entrepreneurs in an ethnically mixed neighbourhood (characterised by ethnic pluralism) have higher growth aspirations.

\section{Business discussion networks as social capital}

Entrepreneurs are embedded in personal networks, which may facilitate their actions (Hansen, 1995; Casson and Della Giusta 2007; Jack et al., 2010). Personal networks enable individuals to obtain knowledge and information, such as contacts for new customers, or new business opportunities (Greve and Salaff, 2003; Hoang and Antoncic, 2003; Jack, 2010; Witt, 2004) and this is likely to feed into entrepreneurial growth aspirations. Networks can also provide access to different types of resources that either would not otherwise be available, or would be more expensive to obtain via the market. Relying on networks may be a useful strategy to overcome constraints to growth such as accessing finance, finding appropriately qualified human resources, and also dealing with institutional and regulatory obstacles such as customs regulations or obtaining commercial licences. This latter aspect suggests why business networks may become a substituting strategy in environments characterised by weak institutions and weak trust, enhancing growth aspirations of entrepreneurs (Estrin, Korosteleva and Mickiewicz, 2013).

Moreover, the composition of individuals' networks affects the ability of entrepreneurs to obtain a variety of information and resources (Raiser et al., 2007; Jack et al., 2010; Watson, 2011; Zang, 2011). A central debate in the literature on network structure concerns whether strong or weak ties bring more benefits to individuals (Granovetter, 1973; Krackhardt, 1992; Greve and Salaff, 2003; Wang and Altinay, 2012). While close ties (especially family based) may provide the entrepreneur with emotional and motivational support, weak ties may result in access to non-redundant knowledge and information. However, we posit that to understand the impact of network structure, we need further to distinguish between acquaintances and friends (e.g. Krackhardt and Stern, 1988; Greve and Salaff 2003). While more valuable knowledge may indeed be found when reaching out beyond the family circle, the extent to which it can be effectively acquired relies on the attitudes of outside contacts and the degree of trust between the individuals in the network. Obtaining valuable knowledge and resources from weak ties may be particularly difficult in the post-conflict environment, where the social tissue has been damaged, the level of trust is low, and people are unwilling to share knowledge with strangers or mere acquaintances. In such environments, to be able to benefit from business contacts, strong personal links need to be built on top of these. Accordingly, we hypothesise:

Hypothesis 4: Growth aspirations are enhanced by a larger proportion of ties that are family or friends based (in contrast with acquaintances).

\section{Hired managers versus owners-managers}

In a recent paper that discusses research agenda on the entrepreneurial process, Wright and Marlow (2011: 112) notice that "different ownership profiles critically influence entrepreneurial ambitions and activities. Consequently, future work needs to recognize how ownership structures profoundly affect the development of the venture." This implies a call for incorporating some of the corporate governance insights into entrepreneurship research. Broadly speaking, these insights relate to both relations between owners, and relations between owners and managers; these two aspects correspond to horizontal and vertical corporate governance (e.g. Roe, 2008). Considering the latter, sound institutional contexts may compensate for strong incentives that come with ownership control in alleviating agency problems. In contrast, where institutional contexts are weak, such as in a post conflict environment, separation of ownership and control may have a particularly negative influence on the way the company is managed, and on its objectives, including growth ambitions.

Thus, in a post-conflict weak institutional environment, the agency costs of separation of ownership and control may be higher, and hired managers may be less likely to realize owners' objectives, if the latter imply adopting high growth aspirations. The managers may find it easier to rely on the informational asymmetry and

\footnotetext{
${ }^{3}$ We are indebted to the anonymous referee to help us improve and extend our discussion of the links between the diversity in the environment and growth aspirations.
} 
realize their own benefits of control, instead of taking risks that come with growth. This motivates us to formulate our Hypothesis 5:

Hypothesis 5: Growth aspirations of owners-managers are higher than those of hired managers.

\section{DATA AND DESCRIPTIVE STATISTICS}

In this research we use data on young businesses obtained through a specially-designed cross-sectional survey implemented in the period June-August 2011. The data was gathered from the owners or managers from six different regions covering the two entities constituting the state of $\mathrm{BiH}-$ the Republic of Srpska and the Federation of Bosnia and Herzegovina. The survey was administered through face-to-face meetings. We chose to survey firms formed between July 2005 and December 2008 to ensure a more homogenised sample, because the business environment for start-ups changed dramatically when the economic crisis hit $\mathrm{BiH}$ in 2009 . $\mathrm{By}$ ending the sample period in 2008 , we avoid mixing together pre-crisis young companies with those started during the crisis. In addition, to achieve more homogeneity, the sample does not include small firms coming from agriculture, forestry, fishing, or craft-workshops. The sample was stratified based on six economic regions, with an average of 40 companies surveyed in each region. In addition, the multi-ethnic division of $\mathrm{BiH}$ between three nationalities is represented in this sample, as each of the three dominant nationalities (Bosniaks, Serbs and Croats) is in majority in two out of these six regions. 734 companies that met the criteria were initially identified for the survey on the basis of public records. There was no size limit applied. The final number of surveyed companies was 244 . Our response rate was $33 \%$. Out of the 490 firms that did not take part in the survey, roughly $15 \%$ did not exist at the time of the survey, $10 \%$ were not at the listed address, and the remaining $75 \%$ did not respond for different reasons. There can be a selection bias related to the fact that some ownersmanagers closed down their businesses in early stage, but like in other studies, finding them would not be easy.

Since we are using survey data, we first checked for missing values as they may produce biased estimates, distort statistical assumptions, and lead to erroneous conclusions (Horton and Lispitz, 2001). Our sample has few missing observations and no observations are missing for the dependent variable. Model 1 is estimated with 227 observations. However, the variables for network composition contain more missing values, so models 2 and 3 are estimated with 166 observations.

The list of the questions we designed to obtain data for our key variables of interest is presented in Table 1 and summary statistics for all variables used in our econometric analysis are reported in Table 2.

$<$ Table 1>

$<$ Table 2>

The dependent variable Employment aspirations utilises the two questions presented in the first row of Table 1 above, which are based on the Global Entrepreneurship Monitor methodology (Reynolds et al., 2005). Combining answers, we produce a continuous variable, capturing the expected percentage change in the number of employees in five years time in comparison to the firm's current situation; this design is based on Estrin, Korosteleva and Mickiewicz (2013). Following these authors we focus on percentage change in employment instead of expected level in five years time, as the percentage change better captures the relative magnitude of aspirations. More specifically, the dependent variable is created as the difference between the firm's employment aspirations in five years time and its current number of employees, divided by the current number of employees. The distribution of dependent variable was left skewed with twelve observations identified as severe outliers (outside the outer fence, using interquartile range). These outliers had unrealistic values in the range of $400 \%-4980 \%$ and consequently were excluded (following Autio and Acs, 2010; Estrin, Korosteleva and Mickiewicz, 2013).

We measure the respondent's perception of the ethnic pluralism in the neighbourhood where they work by the variable Area ethnically mixed. Based on the question presented in Table 1, we constructed this variable to take:

a value of 1 when the respondent perceives either (a) the area is ethnically mixed, or (b) the area contains a balance of two or three major ethnic groups;

- a value of 0 when the respondent perceives their ethnicity to either be (c) in the majority or (d) minority in their work neighbourhood. 
Our conceptualisation that a perception of belonging to an ethnically mixed neighbourhood rather than being in a majority or minority indicates less polarised ethnic relationships seems to be supported by correspondence between our data and what we know about the ethnic composition of BiH. For example, Mostar is a city where different ethnic groups (Croats and Bosniaks) live isolated from one another (in the Western and Eastern parts respectively). In our sample we have a reasonable balance between the two ethnicities. However, perceptions of the ethnic composition of their neighbourhood fall almost unanimously into the ethnic majority category. In contrast, in areas such as Tuzla, where there is also a mix of ethnicities, but not the stark spatial division of ethnicities, this mix is associated with individuals perceiving themselves to live in an ethnically mixed area rather than to be in the majority or minority, entirely consistent with Armakolas (2011). This is illustrated by Figure 2Figure 2 below.

\section{$<$ Figure 2Figure 2>}

Our measure for Generalised trust is based on the World Values Survey (WVS) question as presented in Table 1 above. The response is dichotomous with 0 representing the answer 'need to be very careful' in dealing with people, and 1 representing the response 'most people can be trusted'. From our sample, only $8.2 \%$ of respondents indicated that they possess generalised trust, certainly reflecting both the post-conflict and postCommunist legacy (Estrin and Mickiewicz, 2011a). Data from WVS, which samples the general population rather than focusing on business owners and managers (like this paper), can provide a point of comparison. In the 1999 - 2001 wave of WVS survey (the most recent WVS survey including BiH), 28.3\% of respondents from all the countries sampled, but only $22.2 \%$ in a group of post-communist countries, indicated that they possessed generalised trust. ${ }^{4}$ Interestingly, at $8.2 \%$, the share of managers indicating generalised trust in our sample is lower than found in the World Values survey of the general BiH population in 2001, where the share was $15.8 \%$ (WVS, 2013).

Institutional trust is a scale formed from the respondents' answers to the questions on their confidence in key institutions in $\mathrm{BiH}$ (following Efendic et al., 2011), as listed in Table 1 above. These answers were measured on a scale of 1 (no confidence at all) to 5 (a great deal of confidence). Cronbach's Alpha (0.86) and factor analysis indicate that these items can be combined to form a scale. Accordingly, these individual scores were added together and divided by six to form a scale ranging from 1 to 5 .

In gathering data on networks, we take an ego-centric approach, obtaining data from our respondents' on their personal networks. As an individual's personal network covers all facets of their lives, personal as well as business, and obtaining data on a person's whole network is time consuming and costly, we only look at a subset of an entrepreneur's network - their discussion network, following Greve and Salaff (2003). This is composed of the 'people that entrepreneurs turn to when they discuss aspects of establishing and running a business' (Greve and Salaff, 2003: 3).

We measure the strength (composition) of ties in the respondents network by asking for detail on the strength of the tie for five members of the discussion network. It would be better to have information on all ties, but respondent fatigue makes such data collection very difficult. In examining the role of kin relations in entrepreneurship, Greve and Salaff (2003) argue that restricting the survey to five ties should be adequate.

We define the tie to be strong if the network contact is indicated to be a member of family or a close friend and to be weak if the contact is classified as an acquaintance by the respondent. Following Greve and Salaff's (2003) measure for kin in network, we create the variable \% of external ties in network. This is formed from counting the number of acquaintances named in the five most important ties in network and dividing this by five. As the variable is not continuous, as an alternative we also split it into four categories: no external ties within the first five contacts (49 respondents), one external tie (34 respondents), two external ties (48 respondents), three-five external ties (45 respondents).

Then, we explicitly distinguish between share of ties with family (Family/Total ties), with close friends (Friends/Total ties), and with acquaintances (Acquaintances/Total ties). For each of these categories we calculate the percentage of ties. We take the share of acquaintances as our benchmark omitted category.

\footnotetext{
${ }^{4}$ In 2001 the World Values Survey was implemented in the following post-communist countries: Albania, Bosnia and Herzegovina, Bulgaria, Belarus, Croatia, Czech Republic, Estonia, Hungary, Kyrgyzstan, Latvia, Lithuania, Poland, Romania, Russia, Serbia \& Montenegro, Slovakia, Slovenia \& Ukraine.
} 
Owner-manager status (Owner-manager) is a dichotomous variable where 1 indicates that the individual is both owner and manager of the firm (102 respondents) and 0 indicates all other positions. Apart from managing directors (74 respondents) and owners without any management position (15 respondents), other persons interviewed include deputy directors, deputy managers and similar key management positions in the company strictly delegated either by the owner or manager of the company (53 respondents).

The remaining variables are controls. They include respondent's characteristics and firm characteristics. For firm's characteristics we control for the current number of employees as a proxy for the firm's size (No. of employees) and sector (6 sectors reported in Table 2). For respondent characteristics we include controls for gender (Female), age (Age) and respondent's years of business experience (Business experience).

We also control for discussion network size. Larger networks might be supportive in creating more ambitious business plans through the provision of information and resources (Witt, 2004). Larger networks have been found in empirical research to impact positively on business success, although the evidence is not fully consistent (Jenssen and Greve, 2002; Witt, 2004; Witt et al., 2008). To establish network size, we asked the respondents to approximate the number of people from outside their firm with whom they discussed aspects of running their business (see Table 1). Network size ranges from 0 to 300 but with $90 \%$ of the sample falling in the range 1 to 30 . The size of the network does not have a continuous distribution above the value of eight. There are a few high peaks in distribution, starting with ten; these were clearly taken by the respondents as approximations. Accordingly, we categorised the variable, using cut-off points that partition the empirical distribution into four roughly equal parts. This lead to size of discussion networks categories at $0-3,4-9,10$, and above 10 .

\section{MODEL SPECIFICATION}

The benchmark specification which should capture the factors affecting business aspirations of BiH's young businesses has the following form (corresponding to Model 1 below):

Employment aspirations

$$
\begin{aligned}
& =\hat{\beta}_{0}+\hat{\beta}_{1} \text { Institutional trust }_{i}+\hat{\beta}_{2}{\text { Generalised } \text { trust }_{i}+\hat{\beta}_{3} \text { Area ethnically mixed }}_{i} \\
& +\hat{\beta}_{4} \text { Network's external links }+\hat{\beta}_{5} \text { Ownermanager }+\widehat{\beta_{6}}(\text { Controls })_{i}+\boldsymbol{X} \boldsymbol{\beta}+\hat{\varepsilon}_{i}
\end{aligned}
$$

Indices ' $\mathrm{i}$ ' represent companies $1-244, \hat{\beta}_{0}$ is the constant term, $\hat{\beta}_{1-5}$ are coefficients of variables to be estimated that correspond with hypotheses $1-5, \boldsymbol{X} \boldsymbol{\beta}$ represents the matrix of sectoral fixed effects, while the error term is denoted with $\hat{\varepsilon}$. The hypotheses and variables used to test them as well as the expected signs are I summarised in Table 3Table 3. Generalised trust, Institutional trust and Area ethnically mixed, and Ownermanager are all expected to come with positive sign, consistent with Hypotheses 1-3 and 5. To test our Hypothesis 4, consistent with the discussion in the previous section, we use: share of external ties (External/Total ties), categorisation of this variable, and finally we introduce two categories of ties instead (Model 4) - family (Family/Total ties) and friends (Friends/Total ties), taking acquaintances as a third omitted category.

\section{$<$ Table 3Table 3>}

We control for network size, respondent's characteristics (gender, age, business experience), and firm's characteristics (firm size and sector). We include network size to account for the possibility that the share of external ties masks the effect of larger size, when the latter is omitted from the model. We expect larger size (No. of employees) to have positive effect on the level of growth aspirations of young firms, consistent with empirical evidence that suggest persistence in growth (Wagner, 1992). We expect male gender (Male) to have positive effect on aspirations (Estrin and Mickiewicz, 2011b). We do not have a clear prediction on the effect of age of the respondent (Age) on growth aspirations, as the results in the literature are mixed (Parker, 2009). A conventional view might be that more experience could be associated with higher aspirations (Business experience) indicating a positive sign. In addition, the model controls for different business sectors. Finally, the variables we introduced to represent education were statistically insignificant and/or proved to be incompatible with model diagnostics. Hence, these influences are not included in the final model. A table of correlations between the main variables of interest is reported below.

Formatted: Font: $10 \mathrm{pt}$

Formatted: Font: $10 \mathrm{pt}$ 


\section{RESULTS}

The specifications are estimated by OLS regression in Stata 13 and reported in Table Table-5.

\section{$<$ Table Table $5>$}

We tested our econometric model to ensure correct functional form, and used robust standard errors to mitigate problems with heteroskedasticity. Furthermore, we found no indication of serious multicollinearity in our specifications: the variance inflation factor (VIF) ranges between 2.52 and 3.92 for our variables. While conventional threshold of VIF = 10 may be considered too high (Cohen et al., 2003), the VIFs in our models are far below. In taking both dependent and independent variables from a cross-sectional survey, endogeneity is always a matter of concern. In our study, network size and growth aspirations may be considered particularly problematic as they may be simultaneously defined - individuals with higher growth aspirations may decide to grow their networks in order to meet their aspirations as well as network size having an effect on growth aspirations. However, our variables are constructed so that growth aspirations are forward-looking (we ask about employment growth aspirations for the next five years) and network size is backward-looking (we ask about the networks in the last six months). Furthermore, networks are built and developed slowly overtime, particularly in a low-trust environment and the current network size includes the whole history of network of any particular person. Thus we believe that simultaneity between network size and aspirations is not a serious problem for our study.

Now, we move on to the presentation of results reported in Table Table -5. Institutional trust, capturing (formal) institutional environment is statistically significant in all reported models, at $1 \%$ level in Model 1 based on larger sample, and between 1\% - 5\% level in Models 2-4 based on smaller samples. It correlates positively with growth aspirations in every model reported, supporting Hypothesis 1. Thus, those individuals who have greater confidence in formal institutions report higher growth aspirations. In contrast, we find no evidence supporting Hypothesis 2 - the degree of generalised trust is not statistically significant in any of the models. This may in part be due to the lack of variability in our measure of generalised trust which is only a dichotomous variable.

Next, ethnically mixed areas are characterized by systematically greater growth aspirations in comparison to more homogenous areas, clearly supporting Hypothesis 3, at 1\%o level in Model 1 (larger sample), and at 1\% in Models 2-4 (smaller sample). To verify if our results are indeed related to ethnic pluralism and not enforced by categorisation and by combining the answers' categories, we also applied alternative specifications (unreported but available on request) where we distinguish between majority and minority perceptions using separate Ethnic majority and Ethnic minority variables. However, according to the Wald test, the difference between the coefficients for Ethnic majority and Ethnic minority is statistically insignificant. Consequently, we use Area ethnically mixed in our final models.

To investigate the relationship between the composition of networks and aspirations (Hypothesis 4) we first apply the External/Total ties variable (Model 2), defining - as discussed above - the strength of the network ties in terms of external weak ties versus internal strong ties. We find a highly significant effect (at $1 \%$ ), suggesting that the proportion of strong ties rather than weak ties is positively related to business aspirations. Next in Model 3 , we replace this measure with categorisation of the external ties indicator. The significance of the effect increases with the share of external contacts. Remarkably, the aspirations are lowered by half, for the respondents whose business discussion networks are dominated by acquaintances ( 3 or more out of 5 contacts), compared with the respondents whose five first business discussion partners consist entirely of family or friends. To further test the robustness of our result on network composition, in Model 4, we next distinguish between family-based strong ties (Family/Total ties), friends-based strong ties (Friends/Total ties) and ties with acquaintances. While it appears that the proportion of friends-based strong ties has a stronger effect on business aspirations compared with the family-based strong ties; when we performed the Wald test on difference between these coefficients, it came out as insignificant. It is not the difference between family and others but the difference between family and friends versus others that matters.

With respect to the distinction between owners-managers and hired managers, we found support for Hypothesis 5; that is owners-managers exhibit higher growth aspirations. Consistent with Model 1, ownersmanager are characterised by $20 \%$ higher growth aspirations compared with hired managers. The result is

Formatted: Font: $10 \mathrm{pt}$

Formatted: Font: $10 \mathrm{pt}$

Formatted: Font: $10 \mathrm{pt}$ 
significant at conventional 5\% level, but weaker once the sample becomes smaller in Models 2-4 (significant at $10 \%)$.

With respect to our controls, we find that a large network size (over 10 people in business discussion network) is significant at $5 \%$ and positively associated with higher aspirations in Model 1, but again the significance level is at $10 \%$ when the size of the sample becomes smaller and the composition variables are added. In particular, being a female has a positive and significant effect in the model suggesting that females have systematically higher growth aspirations than males. This result goes against conventional findings (see, for example, Estrin and Mickiewicz, 2011b) and is rather surprising, as BiH's society still might be considered as rather patriarchal society in which women are less engaged in the social, political, and economic aspects of life compared to men (Somun-Krupalija, 2011). It may be that our results are driven by self-selection: in such a climate, where the obstacles to female entrepreneurship are higher, only the most ambitious women succeed in becoming entrepreneurs.

\section{DISCUSSION AND CONCLUSIONS}

We deal with the influence of multiple dimensions of social capital on entrepreneurial growth aspirations, in a post-conflict context. We develop hypotheses that relate to the aspirations of the managers of young businesses. Following Penrose (2009 [1959]) we take managers seriously, as we do not see companies as black boxes, where different input combinations produce alternative outcomes. Growth results from entrepreneurial ambitions, and the latter belong to entrepreneurs. However, what makes the question particularly interesting is a non-standard context, where entrepreneurs' ambitions may be seriously affected by their social linkages and perceptions, as they operate in an environment hostile to business expansion.

Consistent with this, we consider social dimensions of ethnic pluralism, institutional and generalised trust, and business network composition in the post-conflict context, which implies that social capital is fragile yet it also matters greatly. In addition, in this challenging institutional environment, the difference in aspirations between owners-managers and hired managers may become particularly important.

We found that the institutional trust exhibited by a manager is associated with stronger business aspirations. Considerable variation in the individual level of institutional trust suggests that aspects of social capital that have been attributed to the nationwide level (Fukuyama, 1995) have more localised character, and this applies in particular to societies emerging from internal conflicts. This links to an observation by De Soto (2001), who opens his institutional analysis by noticing how much the institutional perceptions in the same country differ amongst the business people located in different environments. Thus, we argue that a micro perspective on formal institutions is valuable, as in a post-conflict weak institutional context there is a significant variance in individual experience of institutions, and better experience is associated with more entrepreneurial dynamism. Thus, from the policy perspective, our findings suggest that much can be achieved by emulating already existing best local practice. The latter policy approach will also come with lower risks related to 'institutional transplants' from far away (Mamadouh, De Jong and Lalenis, 2002).

We argue next that in context where ethnic tensions are a salient issue, local ethnic pluralism is an important factor affecting employment growth aspirations via norms of tolerance supporting experimentation, via broader knowledge base and via wider access to resources, human capital in particular. We found that managers in local areas that are ethnically mixed rather than fragmented and polarised into majority and minority groups, have higher growth aspirations. These results are important when seen in the context of the cross-country economic literature, as the latter suggests that ethnic fractionalisation may be associated with negative economic outcomes. This conclusion may be correct to the extent the fractionalisation is associated with likelihood of internal conflicts. However, Collier (2008) argues that ethnic diversity in the post conflict context is associated with lower risks where some basic democratic institutions are in place, as in our case.

While the strength of business ties in the literature is recognized as a potential determinant of business aspirations, the empirical results are ambiguous (Greve and Salaff, 2003). We offer a suggestion where the ambiguity may be coming from. While strong ties provide young businesses with limited amount of new knowledge, networks based on external weak ties may potentially offer more valuable resources. Yet, in a weak trust environment, these will not be utilised effectively, unless the external ties become considerably strengthened. This is captured by the difference between acquaintances and friends. In the latter case, trust, resulting from transforming external ties into stronger ones, enables managers of young businesses to access more valuable knowledge. 
Moreover, here we can bring together our evidence on network composition and institutional trust and contrast it with insignificant results on generalised trust. What this may suggest is that managers of young companies may rely on their local discussion networks to compensate for lack of (generalised) trust in strangers. However, it is more difficult to compensate for obstacles created by formal institutions: it may be this difficulty in finding alternative managerial strategies that explains why the local perception of formal institutions plays such a significant role. Our results echo Aidis and Mickiewicz (2006) who found that while experience of weak institution (as exemplified by corruption) was not prevalent amongst businesses in a transition country (Lithuania), it did affect growth expectations the most: the businesses that encountered corruption in their local environment did reduce their growth aspirations significantly.

Finally, in weak institutional contexts, ownership matters. Owners-managers of young companies exhibit higher growth aspirations than hired managers. We posit that in such a context, alignment of objectives is more difficult between owners and hired managers. We expected to find this positive divergence, but we should note that there are also some counterarguments. Owners may be more entrepreneurial than managers, but it may also be that they are less willing to take onto themselves risks that come with growth, as they have more at stake, and they may also be driven by independence motive, which suggest less risk taking and less debt taking; the latter being typically associated with expansion (Penrose 1959 [2009]). It turned out, that in the context we consider, owners-managers are indeed more entrepreneurial than hired managers as documented by their growth aspirations. This has clear practical implications for entrepreneurs, as founders of such companies should be aware of the trade-offs involved.

While this study is based on one country, we believe that our framework is applicable to other post-conflict environments that suffered from ethnic hatred and violence and are in a process of reconstruction. This also suggests lines of future research. A clear limitation of this study is that we cannot be sure if our conclusions would be supported if extrapolated to other locations, with different cultural contexts, formal institutions, and ethnic composition. It would also be useful to have a similar comparator country with no history of conflict and ethnic divisions. Another valuable extension would be to consider the decision to start a company and subsequent growth aspirations jointly, based on a longitudinal design.

Our findings highlight the importance of different social determinants for policies aimed at supporting young business development and have particular resonance for post-conflict areas. The entrepreneurs' trust in institutions as well as stronger social ties beyond the family circle are both associated with higher business growth aspirations. Equally important, ethnic pluralism is an opportunity not a threat: in the regions where ethnic pluralism is preserved, business aspirations are stronger.

\section{REFERENCES}

Acemoglu D \& Robinson J (2012) Why Nations Fail. London: Profile Books.

Acs Z (2006) Start-ups and entry barriers: small and medium sized firms population dynamics. In: Casson M, Yeung B, Basu A \& Wadeson N (eds) The Oxford Handbook of Entrepreneurship. Oxford: Oxford University Press, pp. 194-224.

Adler P \& Kwon S (2002) Social capital: prospects for a new concept. Academy of Management Review 27(1): $17-40$.

Aidis R \& Mickiewicz T (2006) Entrepreneurs, expectations and business expansion: lessons from Lithuania. Europe-Asia Studies, 58 (6): 855-880.

Aidis R, Estrin S \& Mickiewicz T (2008) Institutions and entrepreneurship development in Russia: A

comparative perspective. Journal of Business Venturing 23: 656-672.

Aldrich HE. \& Kim PH (2007) Small worlds, infinite possibilities? How social networks affect entrepreneurial team formation and search. Strategic Entrepreneurship Journal 1: 147-165.

Alesina A \& La Ferrara E (2005) Ethnic diversity and economic performance. Journal of Economic Literature 43(3): $762-800$.

Armakolas I (2011) The paradox of Tuzla City: Explaining non-nationalist local politics during the Bosnian war. Europe-Asia Studies 63(2): 229-261.

Arrow KJ (1974) The Limits of Organization. New York: Norton.

Audretsch D, Dohse D \& Niebuhr A (2010) Cultural diversity and entrepreneurship: a regional analysis for Germany. The Annals of Regional Science 45(1): 55-85.

Autio E \& Acs Z (2010) Intellectual property protection and the formation of entrepreneurial growth aspirations. Strategic Entrepreneurship Journal 4(3): 234-251.

Autio E (2011) High aspiration entrepreneurship. In: Minniti M. (edt) Dynamics of Entrepreneurship. Oxford: Oxford University Press, pp. 251-276. 
Baum JR, Locke EA \& Kirkpatrick SA (1998) A longitudinal study of the relation of vision and vision communication to venture growth in entrepreneurial firms. Journal of Applied Psychology 83(1): 43-54.

Baum JR, Locke EA \& Smith KJ (2001) A multidimensional model of venture growth. Academy of Management Journal 44(2): 292-303.

Bieber F (2006) Post-war Bosnia: Ethnicity, Inequality \& Public Sector Governance. Basingstoke: Palgrave Macmillan.

Bieber F (2010) Bosnia and Herzegovina since 1990. In: Ramet S. P. (ed) Central and Southeast European Politics Since 1989. Cambridge: Cambridge University Press, pp. 311-328.

Bourdieu P (1986) The forms of capital. In: Richardson J. (ed) Handbook of Theory and Research for the Sociology of Education. New York: Greenwood, pp. 241-258.

Bowen HP, De Clercq D (2008) Institutional context and allocation of entrepreneurial effort. Journal of International Business Studies 39(4): 747-767.

Burt RS (2000) The network structure of social capital. Research in Organisational Behaviour 22: 345-423.

Casson M, Della Giusta M (2007). Entrepreneurship and social capital. International Small Business Journal, 25(3): 220-244.

Cohen J, Cohen P, West S \& Aiken L (2003) Applied Multiple Regression / Correlation Analysis for the Behavioural Sciences. Abington: Routledge.

Collier P (2008) The Bottom Billion. Oxford: Oxford University Press.

De Soto H (2001) The Mystery of Capital. London: Black Swan.

Delmar F \& Wiklund J (2008) The effect of small business managers' growth motivation on firm growth: a longitudinal study. Entrepreneurship Theory and Practice 32(3): 437-457.

Dyrstad K (2012) After ethnic civil war: Ethno-nationalism in the Western Balkans. Journal of Peace Research 49: $817-831$.

Easterly W \& Levine R (2001) Africa's growth tragedy: policies and ethnic divisions. Quarterly Journal of Economics 112: 1203-1250.

Efendic A, Pugh G \& Adnett N (2011) Confidence in formal institutions and reliance on informal institutions in $\mathrm{BiH}$ : an empirical investigation using survey data. Economics of Transition 19(3): 531-540.

Estrin S \& Mickiewicz T (2011a) Entrepreneurship in transition economies: the role of institutions and generational change. In: Minniti M. (ed) Dynamics of Entrepreneurship. Oxford: Oxford University Press, pp. 181-208.

Estrin S \& Mickiewicz T (2011b) Institutions and female entrepreneurship. Small Business Economics 37(4): $397-415$.

Estrin S, Korosteleva J \& Mickiewicz T (2013) Which institutions encourage entrepreneurial growth aspirations? Journal of Business Venturing, 28 (4) 564-580.

Estrin S, Mickiewicz T, \& Stephan U (2013). Entrepreneurship, social capital, and institutions: Social and commercial entrepreneurship across nations. Entrepreneurship Theory and Practice 37(3): 479-504.

Florida R (2004) The Rise of Creative Class. New York: Basic Books.

Florida R (2005) Cities and the Creative Class. London: Routledge.

Fukuyama F (1995) Trust: the Social Virtues and the Creation of Prosperity. London: Penguin.

Fukuyama F (2001). Social capital, civil society and development. Third World Quarterly 22: 7-20.

Gedajlovic E, Honig B, Moore C, Payne G, Wright M (2013) Social capital and entrepreneurship: a schema and research agenda. Entrepreneurship Theory and Practice, 37(3): 455-478.

Glaeser E, Scheinkman J \& Shleifer A (2003) The injustice of inequality. Journal of Monetary Economics 50: 199-222.

Granovetter M (1973) The strength of weak ties. American Journal of Sociology 78(3): 1360-1380.

Granovetter M (1985) Economic action and social structure: the problem of embeddedness. The American Journal of Sociology 91(3): 481-510.

Greve A \& Salaff JW (2003) Social networks and entrepreneurship. Entrepreneurship Theory \& Practice 28(1): $1-22$.

Hadziahmetovic A (2011) Ekonomija Evropske Unije. Sarajevo: University Press.

Halpern D (2005) Social Capital. Cambridge: Polity.

Hansen EL (1995) Entrepreneurial networks \& new organizational growth. Entrepreneurship Theory \& Practice 19(4): 7-19.

Henrekson M \& Johansson D (2010) Gazelles as job creators: a survey and interpretation of the evidence. Small Business Economics 35(2): 227-244.

Hoang H \& Antoncic B (2003) Network-based research in entrepreneurship: a critical review. Journal of Business Venturing 18(2): 165-187.

Hodson R, Sekulic D and Massey G (1994) National tolerance in the former Yugoslavia. American Journal of Sociology 99(6): 1534-1558. 
Horton NJ and Lipsitz SR (2001) Multiple imputation in practice: comparison of software packages for regression models with missing variables. The American Statistician 55 (August): 244-254.

Hohmann HH \& Welter F (2002) Entrepreneurial strategies and trust: structure and evolution of entrepreneurial behavioural patterns. In: Hohmann HH \& Welter F (eds) East and West European Environments Concepts and Considerations. Forschungsstelle Osteuropa, Arbeitspapiere und Materialine, 37, Bremen: Universitat Bremen, pp. 11-18.

Jack S (2010) Approaches to studying networks: implications and outcomes. Journal of Business Venturing 25(1): 120-137.

Jack S, Moult S, Anderson AR \& Dodd S (2010) An entrepreneurial network evolving: patterns of change. International Small Business Journal 28(4): 315-337.

Kelley DJ, Bosma N \& Amorós JE (2010) Global Entrepreneurship Monitor: 2010 Global Report, Babson Park, MA: Babson College.

Kolvereid L \& Bullvag E (1996) Growth intentions and actual growth: the impact of entrepreneurial choice. Journal of Enterprising Culture 4(1): 1-17.

Krackhardt D \& Stern RN (1988) Informal networks and organizational crises: An experimental simulation. Social Psychology Quarterly 51(2): 123-140.

Krackhardt D (1992) The strength of strong ties: The importance of philos in organizations. In Nohria N \& Eccles RG (eds) Networks and Organizations: Structure, Form, and Action, Boston, MA: Harvard Business School Press, pp. 216-239.

Kwon SW \& Arenius P (2010) Nations of entrepreneurs: a social capital perspective. Journal of Business Venturing 25(3): 315-330.

Lee SY, Florida R \& Acs Z (2004) Creativity and entrepreneurship: a regional analysis of new firm formation. Regional Studies 38(8): 879-891.

Levie J \& Autio E (2011) Regulatory burden, rule of law and entry of strategic entrepreneurs: an international panel study. Journal of Management Studies 48(6): 1467-6486.

Light I and Dana LP (2013). Boundaries of social capital in entrepreneurship. Entrepreneurship Theory and Practice 37(3): 603-624.

Marino M, Parrotta P \& Pozzoli D (2012) Does labour diversity promote entrepreneurship?. Economic Letters 116(1): 15-19.

Mamadouh, V, De Jong, M, \& Lalenis, K (2002). The Theory and Practice of Institutional Transplantation. Dordrecht: Springer Netherlands.

Messersmith JG \& Wales WJ (2011) Entrepreneurial orientation and performance of young firms: The role of human resource management. International Small Business Journal 31(2): 115-136.

Nooteboom B (2007) Social capital, institutions and trust. Review of Social Economy 65(1): 29-53.

Olson M (1982) The Rise and Decline of Nations: Economic Growth, Stagflation, and Social Rigidities. Yale: Yale University Press.

Paldam M (2000) Social capital: one or many? Definition and measurement. Journal of Economic Surveys 14(5): 629-653.

Parker S (2009) The Economics of Entrepreneurship. Cambridge: Cambridge University Press.

Penrose E (2009 [1959]) The Theory of the Growth of he Firm. Oxford: Oxford University Press.

Pettigrew TF (1998) Intergroup contact theory. Annual Review of Psychology 49(1): 65-85.

Putnam RD (2000) Bowling Alone: The Collapse and Revival of American Community. New York: Simon and Schuster.

Putnam RD (2007) E pluribus unum: Diversity and Community in the Twenty-first century. The 2006 Johan Skytte Prize Lecture. Scandinavian Political Studies 30(2): 137-74.

Raiser M (1999) Trust in transition. EBRD Working Paper No. 39.

Raiser M, Rousso A, Steves F \& Teksoz U (2007) Trust in transition: cross-country and firm evidence. The Journal of Law, Economics \& Organization 24(2): 407-433.

Ram M, Jones T, Edwards P, Kiselinchev A, Muchenje L and Woldesenbet K (2011) Engaging with superdiversity: New migrant businesses and the research-policy nexus. International Small Business Journal 31(4): 337-356.

Reynolds PD, Bosma N, Autio E, Hunt S, De Bono N, Servais A, Lopez-Garcia P \& Chin N (2005) Global entrepreneurship monitor: Data collection design and implementation 1998-2003. Small Business Economics 24: 205-231.

Roe M (2008) The institutions of corporate governance. In: Ménard, C. \& Shirley, M. (eds.) Handbook of New Institutional Economics, pp. 371-400. Berlin: Springer.

Rothstein B (2003) Social capital, economic growth and quality of government: the causal mechanism. New Political Economy 8(1): 49-71.

Rothstein B \& Stolle D (2008) The state and social capital: an institutional theory of generalized trust, Comparative Politics 40(4): 441-459 
Rus A \& Iglič H (2005) Trust, governance and performance. The role of institutional and interpersonal trust in SME development. International Sociology 20(3): 371.391.

Smallbone D, Kitching J \& Athayde R (2010) Ethnic diversity, entrepreneurship and competitiveness in a global city. International Small Business Journal 28(2): 174-190.

Sobel J (2002) Can we trust social capital? Journal of Economic Literature 40(1): 139-154.

Somun-Krupalija L (2011) Gender and employment in Bosnia and Herzegovina - A country study, International Labour Office Bureau for Gender Inequality. Geneva: ILO $20111 \mathrm{v}$

Stephan U \& Uhlaner LM (2010) Performance based vs. socially supportive culture: a cross-national study of descriptive norms and entrepreneurship. Journal of International Business Studies 41(8): 1347-1364.

UNDP (2009) The Ties That Bind - Social Capital in Bosnia and Herzegovina. The National Human Development Report. Sarajevo: UNDP.

Van Stel A \& Storey D (2004) The link between firm births and job creation: is there an upas tree effect? Regional Studies 38(8): 893-909.

Wagner J (1992) Firm size, firm growth, and persistence of chance. Small Business Economics 4: 125-131.

Wang CL \& Altinay L (2012) Social embeddedness, entrepreneurial orientation and firm growth in ethnic minority small business in the UK. International Small Business Journal 30(1): 3-23.

Watson J (2011) Networking: gender differences and the association with firm performance. International Small Business Journal 30(5): 536-558.

Welter F \& Smallbone D (2006) Exploring the role of trust in entrepreneurial activity. Entrepreneurship Theory and Practice 30(4): 465-475.

Welter F (2012) All you need is trust? A critical review of the trust and entrepreneurship literature. International Small Business Journal 30(3): 193-212.

Westlund H \& Adam F (2010) Social capital and economic performance: a meta-analysis of 65 studies. European Planning Studies 18(6): 893-919.

Wiklund J \& Shepherd D (2003) Aspiring for and achieving growth: the moderating role of resources and opportunities. Journal of Management Studies 40(8): 1919-1941.

Witt P (2004) Entrepreneurs' network and success of start-ups. Entrepreneurship and Regional Development 16(5): 391-412.

Witt P, Schroeter A \& Merz C (2008) Entrepreneurial resource acquisition via personal networks: an empirical study of German startu-ups, The Service Industries Journal 28(7): 953-971.

Wong PK, Ho YP \& Autio E (2005) Entrepreneurship, innovation and economic growth: Evidence from GEM data. Small Business Economics 24(3): 335-350.

World Bank (1997) Bosnia and Herzegovina From Recovery to Sustainable Growth: Washington DC: World Bank.

World Bank (2002) Building Institutions for Markets - World Development Report 2002. New York, Oxford: Oxford University Press.

Wright M, Marlow S (2011) Entrepreneurial activity in the venture creation and development process. International Small Business Journal 30(2): 107-114.

Wright M \& Stigliani I (2012) Entrepreneurship and growth. International Small Business Journal 31(1): 3-22.

Zain M \& Ng SI (2006). The impacts of network relationships on SMEs' internationalization process.

Thunderbird International Business Review, 48: 183-205.

Zang J (2011) The problems of using social networks in entrepreneurial resource acquisition. International Small Business Journal 28(4): 338-361.

Zucker LG (1986) The production of trust: institutional sources of economic structure, 1840-1920. Research in Organization Behaviour 8: 53-111. 
Figure 1: Theoretical framework

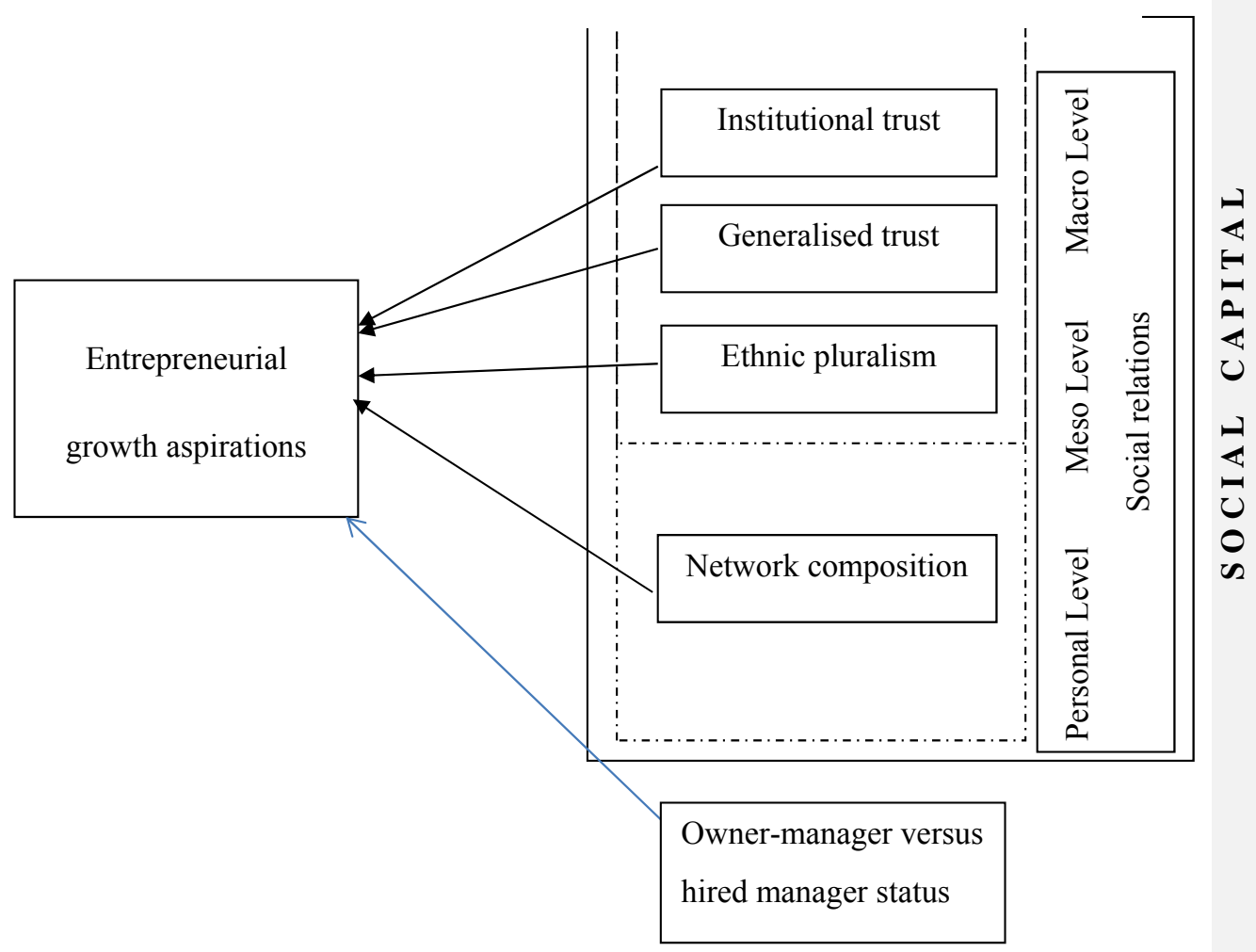

P O S TC ONFLICT E N V I R O N M E N T 
Figure 2: Bar charts showing ethnicity and perceptions of neighbourhood ethnic diversity

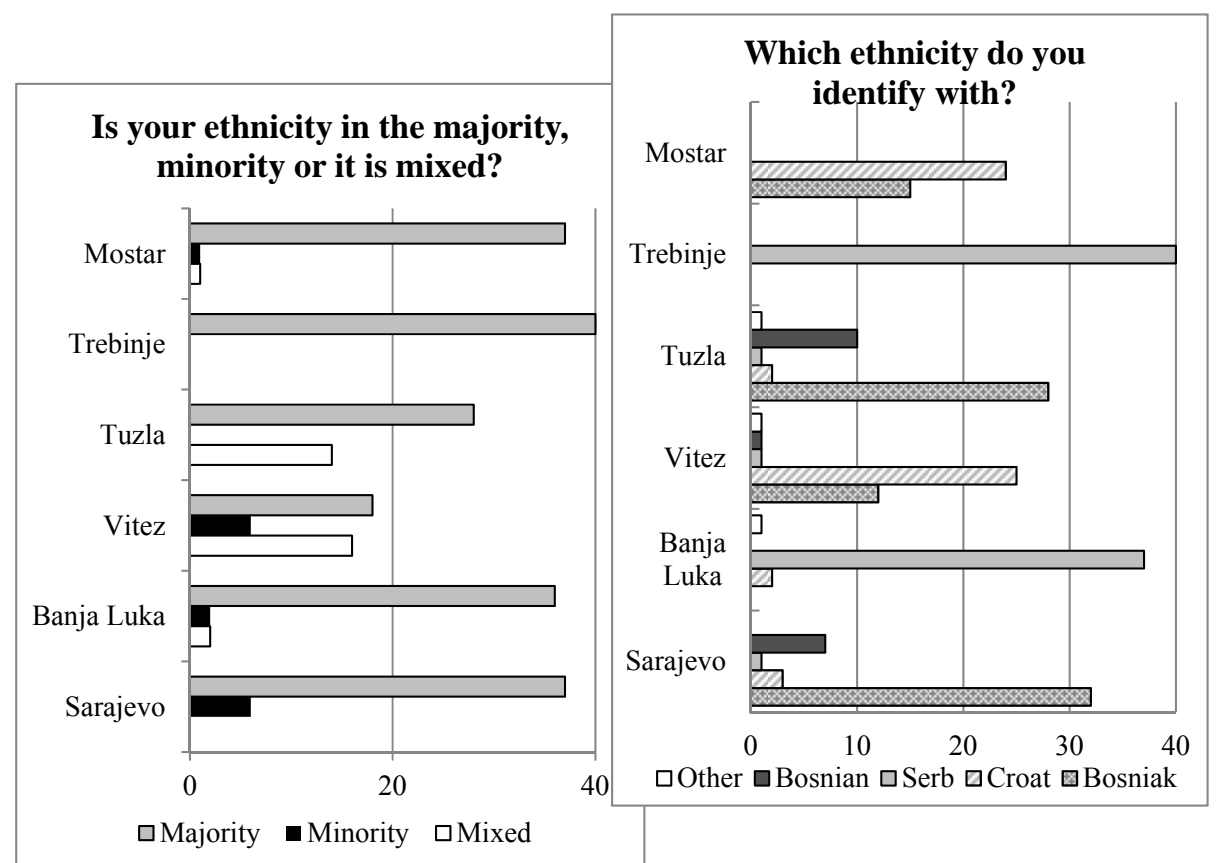

Note: The question on ethnic self-identification was open ended. In addition to the three major ethnic groups, some respondents declared their ethnicity more broadly as 'Bosnian'. 
Table 1: Questions used to obtain data for key variables

\begin{tabular}{|c|c|}
\hline Variable name & Question \\
\hline Employment aspirations & $\begin{array}{l}\text { What is the total number of employees in your enterprise currently? } \\
\text { What is the total number of employees in your enterprise expected in } 5 \text { years time? }\end{array}$ \\
\hline Area ethnically mixed & $\begin{array}{l}\text { In the neighbourhood where you work now, is your ethnic group in the } \\
\text { (1) majority } \\
\text { (2) minority } \\
\text { (3) there is a balance between two or three major groups } \\
\text { (4) it is diverse }\end{array}$ \\
\hline Generalised trust & $\begin{array}{l}\text { Generally speaking, would you say that most people can be trusted or that you } \\
\text { need to be very careful in dealing with people? } \\
\text { (1) Most people can be trusted } \\
\text { (2) Need to be very careful }\end{array}$ \\
\hline Institutional trust & 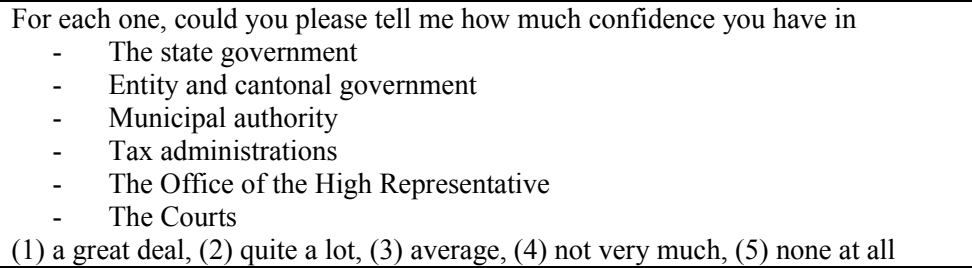 \\
\hline Network size & $\begin{array}{l}\text { Thinking about the last } 6 \text { months, with approximately how many people from } \\
\text { outside your firm do you discuss aspects of running your business either to get } \\
\text { new information, advice or to check your own ideas? }\end{array}$ \\
\hline$\%$ external ties & $\begin{array}{l}\text { Please can you think about the people from outside your firm with whom you } \\
\text { regularly discuss aspects of running your own business. Write down the initials for } \\
\text { up to } 5 \text { of them (Interviewer asked about each person). Is this contact a: } \\
\text { (1) Acquaintance } \\
\text { (2) Close friend } \\
\text { (3) Family member }\end{array}$ \\
\hline $\begin{array}{l}\text { Owners-managers versus } \\
\text { hired managers }\end{array}$ & $\begin{array}{l}\text { Are you the owner of this firm? } \\
\text { Are you the manager of this firm? }\end{array}$ \\
\hline
\end{tabular}


Table 2: Descriptive statistics

\section{Employment aspirations}

(expected change in number of employees)

Area ethnically mixed

(mixed $=1$, otherwise $=0$ )

Ethnic majority

(majority $=1$, otherwise $=0$ )

Ethnic minority

$($ minority $=1$, otherwise $=0)$

Generalised trust

(most people can be trusted: yes $=1$, no $=0$ )

Institutional trust

( confidence in institutions: none $=1$, a great deal $=5$ )

$\%$ of external ties in network

(no external ties $=0$, all ties external $=1$ )

Owner-manager of firm

(respondent owner-manager of firm $=1$, otherwise $=0$ )

Network size (continuous)

(no. of people in discussion network)

Network size 0 - 3

(network size: $0-3$ people $=1$, otherwise $=0$ )

Network size 4 -9

(network size: $4-9$ people $=1$, otherwise $=0$ )

Network size 10

(network size: 10 people $=1$, otherwise $=0$ )

Network size over 10

(network size: $11+=1$, otherwise $=0$ )

Feale

$($ male $=0$, female $=1)$

Age

(Age of respondents in years)

Business experience

(Business experience in years)

No. of employees

(current number of employees)

Manufacturing

(firm's main sector manufacturing $=1$, otherwise $=0$ )

Hotels

(firm's main sector hotels)

Construction

(firm's main sector construction $=1$, otherwise $=0$ )

Transport

(firm's main sector transport $=1$, otherwise $=0$ )

Trade

(firm's main sector trade $=1$, otherwise $=0$ )

Business services

(firm's sector business services $=1$, otherwise $=0$ )

\begin{tabular}{|c|c|c|c|c|c|}
\hline Mean & Median & SD & Min & Max & No. obs \\
\hline 6.53 & 0.5 & 41.41 & -1 & 498.5 & 243 \\
\hline 0.14 & 0 & 0.34 & 0 & 1 & 243 \\
\hline 0.80 & 1 & 0.40 & 0 & 1 & 243 \\
\hline 0.06 & 0 & 0.24 & 0 & 1 & 243 \\
\hline 0.08 & 0 & 0.27 & 0 & 1 & 243 \\
\hline 2.46 & 2.5 & 0.72 & 1 & 4.3 & 243 \\
\hline 0.32 & 0.4 & 0.27 & 0 & 1 & 176 \\
\hline 0.42 & 0 & 0.49 & 0 & 1 & 243 \\
\hline 14.49 & 9 & 31.66 & 0 & 300 & 243 \\
\hline 0.30 & 0 & 0.46 & 0 & 1 & 243 \\
\hline 0.20 & 0 & 0.40 & 0 & 1 & 243 \\
\hline 0.26 & 0 & 0.44 & 0 & 1 & 243 \\
\hline 0.23 & 0 & 0.42 & 0 & 1 & 243 \\
\hline 0.33 & 1 & 0.42 & 0 & 1 & 243 \\
\hline 38.63 & 38 & 9.80 & 20 & 79 & 243 \\
\hline 9.98 & 7 & 7.66 & 1 & 40 & 243 \\
\hline 11.01 & 4 & 28.99 & 1 & 400 & 243 \\
\hline 0.09 & 0 & 0.29 & 0 & 1 & 243 \\
\hline 0.03 & 0 & 0.18 & 0 & 1 & 243 \\
\hline 0.06 & 0 & 0.24 & 0 & 1 & 243 \\
\hline 0.03 & 0 & 0.17 & 0 & 1 & 243 \\
\hline 0.45 & 0 & 0.50 & 0 & 1 & 243 \\
\hline 0.33 & 0 & 0.47 & 0 & 1 & 243 \\
\hline
\end{tabular}


Table 3: Summary of hypotheses

\begin{tabular}{|l|l|c|}
\hline Hypothesis & Variable used to test hypothesis & Expected sign \\
\hline $\begin{array}{l}\text { H1: The greater entrepreneurs' trust in institutions, the } \\
\text { higher their growth aspirations. }\end{array}$ & Institutional trust & + \\
\hline $\begin{array}{l}\text { H2: The greater entrepreneurs' generalised trust, the } \\
\text { higher their growth aspirations. }\end{array}$ & Generalised trust & + \\
\hline $\begin{array}{l}\text { H3: Entrepreneurs in an ethnically mixed } \\
\text { neighbourhood have higher growth aspirations. }\end{array}$ & Area ethnically mixed & + \\
\hline $\begin{array}{l}\text { H4: Growth aspirations are enhanced by a larger } \\
\text { proportion of ties that are strong (family and friends } \\
\text { based). }\end{array}$ & External/Total ties \\
\hline $\begin{array}{l}\text { H5a: Growth aspirations of owners-managers are } \\
\text { higher. } \\
\text { H5b: Growth aspirations of hired managers are higher. }\end{array}$ & Owner-manger & - \\
\hline
\end{tabular}


Table 4: Correlations

$\begin{aligned} 1 & \text { Employment Aspirations } \\ 2 & \text { Area Ethnically Mixed } \\ 3 & \text { Institutional Trust } \\ 4 & \text { Generalised Trust } \\ 5 & \text { Network size 4-9 } \\ 6 & \text { Network size 10 } \\ 7 & \text { Network size over 10 } \\ 8 & \text { External / Total Ties } \\ 9 & \text { Family / Total Ties } \\ 10 & \text { Friends / Total Ties } \\ 11 & \text { Owner-Manager } \\ 12 & \text { Male } \\ 13 & \text { Age } \\ 14 & \text { Business Experience } \\ 15 & \text { Number of Employees }\end{aligned}$

1
1
-0.05
-0.10
-0.04
-0.04
0.02
-0.06
$0.19^{*}$
-0.06
$-0.17^{*}$
-0.05
-0.01
$0.11 \dagger$
0.02
-0.03

23

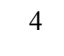

0.03

$0.10 \quad 0.01$

$0.11+\quad 0.02-0.07$

$\begin{array}{lll}0.03 & 0.09 & -0.07 \\ 0.01 & 0.07 & -0.02\end{array}$

0.01

$0.07 \quad-0.02$
$-0.19 * 0.04$

$-0.30^{* *}$

$\begin{array}{ll}-0.19 * & -0.04 \\ 0.19 * & -0.04\end{array}$

$-0.09$

$\begin{array}{llll}0.05 & 0.19 * & -0.04 & 0.06\end{array}$

0.06
0.10
$-0.12+$

$0.06 \quad 0.08$

$\begin{array}{lll}0.05 & -0.14 * & -0.01 \\ 0.01 & 0.05 & 0.09\end{array}$

0.10
$-0.12 \dagger$

$\begin{array}{lll}0.05 & 0.09 & -0.12 \\ 0.04 & 0.02 & -0.02 \\ 0.08 & -0.11 \dagger & 0.01\end{array}$

$\begin{array}{lll}0.08 & -0.11 \dagger & 0.01 \\ -0.04 & -0.04 & -0.05\end{array}$

$-0.33^{* * *}$

$0.03 \quad 0.01$

$\begin{array}{lll}0.02 & 0.05 & -0.55^{* * *}\end{array}$

$\begin{array}{llll}-0.06 & -0.05 & -0.73 * * * & -0.17 *\end{array}$

$-0.12 \dagger \quad 0.00-0.09-0.03 \quad 0.00$

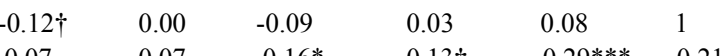

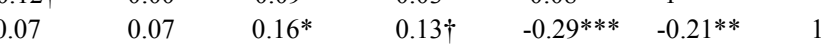

$\begin{array}{lllllll}0.09 & 0.02 & -0.02 & 0.09 & -0.05 & 0.03 & -0.08\end{array}$

$\begin{array}{llllllll}0.22 * * & -0.04 & -0.20 * * & 0.28 * * * & 0.01 & -0.05 & -0.02 & 0.49 * * *\end{array}$

${ }^{* * *} \mathrm{p}<0.001 * * \mathrm{p}<0.01, * \mathrm{p}<0.05, \dagger \mathrm{p}<0.10$ 
Table 5: OLS regression - the dependent variable: employment growth aspirations

\begin{tabular}{|c|c|c|c|c|}
\hline & $(1)$ & (2) & (3) & (4) \\
\hline \multirow[t]{2}{*}{ Area Ethnically Mixed } & $0.442 * * *$ & $0.384 * *$ & $0.369 * *$ & $0.382 * *$ \\
\hline & $(0.121)$ & $(0.122)$ & $(0.120)$ & $(0.121)$ \\
\hline \multirow[t]{2}{*}{ Institutional Trust } & $0.191^{* *}$ & $0.152 *$ & $0.167^{*}$ & $0.153^{*}$ \\
\hline & $(0.062)$ & $(0.076)$ & $(0.079)$ & $(0.075)$ \\
\hline \multirow[t]{2}{*}{ Generalised Trust } & 0.034 & -0.057 & -0.001 & -0.058 \\
\hline & $(0.137)$ & $(0.142)$ & $(0.163)$ & $(0.145)$ \\
\hline \multirow[t]{2}{*}{ External / Total Ties } & & $-0.681 * * *$ & & \\
\hline & & $(0.178)$ & & \\
\hline \multirow[t]{2}{*}{$1 / 5$ external tie } & & & $-0.308^{*}$ & \\
\hline & & & $(0.145)$ & \\
\hline \multirow[t]{2}{*}{$2 / 5$ external ties } & & & $-0.311^{*}$ & \\
\hline & & & $(0.141)$ & \\
\hline \multirow[t]{2}{*}{$3 / 5-5 / 5$ external ties } & & & $-0.501 * * *$ & \\
\hline & & & $(0.129)$ & \\
\hline \multirow[t]{2}{*}{ Family / Total Ties } & & & & $0.638 * *$ \\
\hline & & & & $(0.244)$ \\
\hline \multirow[t]{2}{*}{ Friends / Total Ties } & & & & $0.706 * *$ \\
\hline & & & & $(0.229)$ \\
\hline \multirow[t]{2}{*}{ Owner-Manager } & $0.196^{*}$ & $0.168 \dagger$ & $0.181 \dagger$ & $0.169 \dagger$ \\
\hline & $(0.081)$ & $(0.097)$ & $(0.095)$ & $(0.098)$ \\
\hline \multirow[t]{2}{*}{ Network size 4-9 } & 0.102 & 0.073 & 0.082 & 0.076 \\
\hline & $(0.114)$ & $(0.143)$ & $(0.145)$ & $(0.143)$ \\
\hline \multirow[t]{2}{*}{ Network size 10} & 0.069 & 0.030 & 0.052 & 0.030 \\
\hline & $(0.113)$ & $(0.155)$ & $(0.156)$ & $(0.156)$ \\
\hline \multirow[t]{2}{*}{ Network size over 10} & $0.275^{*}$ & $0.304 \dagger$ & $0.322 \dagger$ & $0.306 \dagger$ \\
\hline & $(0.118)$ & $(0.168)$ & $(0.169)$ & $(0.169)$ \\
\hline \multirow[t]{2}{*}{ Female } & $0.178 \dagger$ & $0.286 * *$ & $0.256^{*}$ & $0.294 * *$ \\
\hline & $(0.096)$ & $(0.103)$ & $(0.105)$ & $(0.110)$ \\
\hline \multirow[t]{2}{*}{ Age } & -0.003 & -0.000 & 0.000 & -0.000 \\
\hline & $(0.005)$ & $(0.006)$ & $(0.006)$ & $(0.006)$ \\
\hline \multirow[t]{2}{*}{ Business Experience } & 0.002 & -0.005 & -0.004 & -0.005 \\
\hline & $(0.006)$ & $(0.008)$ & $(0.008)$ & $(0.008)$ \\
\hline \multirow[t]{2}{*}{ Number of Employees } & -0.001 & -0.001 & -0.001 & -0.001 \\
\hline & $(0.001)$ & $(0.001)$ & $(0.001)$ & $(0.001)$ \\
\hline \multirow[t]{2}{*}{ Manufacturing } & 0.067 & 0.125 & 0.104 & 0.126 \\
\hline & $(0.135)$ & $(0.156)$ & $(0.162)$ & $(0.156)$ \\
\hline \multirow[t]{2}{*}{ Hotels and Restaurants } & $-0.301^{*}$ & $-0.300^{*}$ & $-0.305^{*}$ & $-0.292^{*}$ \\
\hline & $(0.149)$ & $(0.143)$ & $(0.149)$ & $(0.142)$ \\
\hline \multirow[t]{2}{*}{ Construction } & -0.073 & 0.002 & -0.023 & 0.004 \\
\hline & $(0.223)$ & $(0.259)$ & $(0.250)$ & $(0.261)$ \\
\hline \multirow[t]{2}{*}{ Transport } & 0.327 & 0.285 & 0.208 & 0.296 \\
\hline & $(0.334)$ & $(0.353)$ & $(0.348)$ & $(0.353)$ \\
\hline \multirow[t]{2}{*}{ Professional and Business Services } & -0.010 & 0.059 & 0.034 & 0.059 \\
\hline & $(0.094)$ & $(0.114)$ & $(0.116)$ & $(0.114)$ \\
\hline Constant & -0.094 & 0.138 & 0.126 & $-0.555^{*}$ \\
\hline & $(0.226)$ & $(0.283)$ & $(0.290)$ & $(0.262)$ \\
\hline Observations & 227 & 166 & 166 & 166 \\
\hline Adjusted R-squared & 0.144 & 0.209 & 0.206 & 0.204 \\
\hline $\mathrm{F}$ & 3.792 & 4.869 & 4.669 & 4.632 \\
\hline
\end{tabular}

Notes: Robust standard errors in parentheses. $* * * \mathrm{p}<0.001 * * \mathrm{p}<0.01, * \mathrm{p}<0.05, \dagger \mathrm{p}<0.10$ 